\title{
„Ryby rzeczne są zazwyczaj niedorzeczne”. Czego nie potrafi maszyna, czyli o kompetencjach tłumacza i prawach przekładu w kontekście przekładu literackiego
}

\author{
Abstract \\ "Shellfish are Extremely Selfish": What an Automatic Translator Cannot Do. On the Translator's \\ Competence and the Translation Principles in the Context of Literary Translation in the Face of \\ the Ongoing Automation of Translation
}

In view of the emergence of increasingly sophisticated tools for automatic translation, a legitimate question arises: what is the difference between human translation and machine translation, which competence surplus is brought by the human factor, what conditions must be met for human translation to be more perfect than machine translation? The author tries to answer the question discussing different types of competences with particular emphasis on literary competence related to the poetic function of the language. Referring to selected principles of the Translation Studies, postulated in Kubaszczyk (2019), the author argues why human being is still irreplaceable in literary rendering and shows, in reference to Jakobson (1960), how in literary rendering the translator shifts from the selection axis to the combination axis searching for the optimal solution. In the second part of the article, the theoretical argument is supported by empirical evidence.

Keywords: literary rendition, translation competence, literary competence, translation principles, relocation, poetic function, choice, combination, human translation

Słowa kluczowe: przekład literacki, kompetencja tłumaczeniowa, kompetencja literacka, prawa przekładu, relokacja, funkcja poetycka, wybór, kombinacja, przekład ludzki

Na początku jednego z kursowych wykładów przeprowadzam od kilku lat mały eksperyment. Rozdaję studentom kartki, na których przedrukowanych jest dziesięć pierwszych wersów wiersza Wisławy Szymborskiej Urodziny i ich nieco wygładzony maszynowy przekład. Studenci mają za zadanie odpowiedzieć na pyta- 
nie, czy przekład jest ich zdaniem dobry, czy też nie, i dlaczego tak sądzą. Zdania ankietowanych są podzielone. Werdykt zależy od kompetencji początkowych studentów, umiejętności analizy tekstu literackiego i dostrzeżenia jego złożoności oraz zastosowanych przez poetkę środków artystycznych. Wyniki tego minibadania są dla mnie istotne, gdyż pozwala ono ustalić, jaki jest poziom świadomości teoretycznoliterackiej i translatorycznej grupy. Dla studentów owo ćwiczenie stanowi zaś asumpt do refleksji nad tym, że znajomość języka nie wystarcza do tego, by dobrze thumaczyć, bo nie zawsze ,sens”, rozumiany przez nich jako suma znaczeń poszczególnych słów, jest faktycznie „sensem” tekstu, albowiem w istocie nie idzie o ekwiwalenty słów, tylko o coś, co można by nazwać „ideą” utworu.

Prawo idei, jedno z podstawowych, jak sądzę, dla przekładoznawstwa, głosi, że „idea oryginału stanowi wzór dla przekładu i jego rację bytu”" Ową ideę teoretycy przekładu nazywają różnie, zasadniczo jednak chodzi w jej przypadku o:

hipotez[ę] dzieła jako całości, „organizmu” czy „,budowli”, której sens całościowy jest niesprowadzalny do sumy znaczeń poszczególnych składników, lecz stanowi pewną jakość wartościowo wobec nich nadrzędną, daną bezpośrednio, w naocznym wyglądzie².

Odkrycie owej idei, czyli inaczej postawienie hipotezy dzieła jako całości, to pierwsze zadanie thumacza - bez tej umiejętności jego przekłady będą nieudolne i nieudane bądź udane przez „niepojęty przypadek”. W podobnym sensie Barańczak mówi o ustaleniu dominanty semantycznej. Rozumie przez nią prymat „określonego elementu struktury utworu, który stanowi mniej lub bardziej dostrzegalny klucz do całokształtu jego sensów"3. Umiejętność odkrycia czy zrekonstruowania idei za pomocą odpowiednich narzędzi teoretyczno- i krytycznoliterackich jest podstawową kompetencją, która odróżnia profesjonalnego thumacza jako osobę od translatora maszynowego, np. thumacza Google. Google i inne translatory dzięki zastosowaniu technologii neuronowych potrafią już wprawdzie całkiem sprawnie dobrać odpowiednie ekwiwalenty w zależności od kontekstu i w tym sensie coraz bardziej „rozumnie” segmentować i przekładać teksty powtarzalne, jednak mimo ciągłej optymalizacji narzędzi do przekładu automatycznego nadal są one w stanie wygenerować co najwyżej produkt będący sumą znaczeń poszczególnych składników, co udowodnię w dalszej części artykułu. Sprawdzają się zatem coraz lepiej w przypadku tekstów o dominującej funkcji informatywnej, natomiast zawodzą użyte do przekładu tekstów, w których język pełni funkcję poetycką, czyli przede wszystkim utworów literackich oraz niektórych tekstów marketingowych.

Postawienie hipotezy dzieła jako całości wymaga przynajmniej podstawowej wiedzy z zakresu gatunków i rodzajów tekstu, pozwalającej odpowiednio zakwalifikować utwór pod względem gatunkowym i stylowym, wiąże się zatem

1 J. Kubaszczyk, Czy przekladoznawstwo to nauka oparta na solidnym fundamencie? Hipoteza podstawowych praw przekładoznawstwa, „Między Oryginałem a Przekładem” 2019, nr 2(44), s. 20.

2 J. Święch, Przektady i autokomentarze [w:] Polska myśl przekładoznawcza. Antologia, red. M. Heydel, P. de Bończa Bukowski, Kraków [1984] 2013, s. 206.

3 S. Barańczak, Ocalone w thumaczeniu. Szkice o warsztacie thumacza poezji z dodatkiem małej antologii przekładów-problemów, wyd. 3, Kraków 2004, s. 35-36. 
z kolejnymi rodzajami kompetencji, jak kompetencja tekstowa oraz kompetencja ekspercka ${ }^{4}$. Przyjmuję za Bartmińskim, że

t e k s t jest to ponadzdaniowa j e d n o s t k a językowa, makroznak, mający określone nacechowanie gatunkowe i stylowe (kwalifikator tekstu), poddający się całościowej interpretacji semantycznej i komunikatywnej, wykazujący integralność strukturalną oraz spójność semantyczną i podlegający wewnętrznemu podziałowi semantycznemu, a w przypadku tekstów dłuższych - także logicznemu i kompozycyjnemu. W tym sensie tekst nie jest tylko konstrukcją jednostek językowych (wyrazów, zdań), lecz jednostką języka (w sensie przyjmowanym przez Bogusławskiego 1978), o złożonej polifonicznej strukturze ${ }^{5}$.

Z definicji tej wyłania się następna kompetencja tłumacza ludzkiego, której nie posiada maszyna, a mianowicie postrzeganie tekstu jako całości i umiejętność całościowej interpretacji semantycznej i komunikatywnej. Maszyna działa, jak wiadomo, w sensie ponadzdaniowym linearnie ${ }^{6}$. Przekład nie jest jednak działaniem linearnym, choć pewna linearność mu zwykle towarzyszy, w przekładzie może jednak wystąpić i występuje w zakresie węższym lub szerszym relokacja elementów tekstu. Jej skala jest różna w zależności od typu przekładu. W przekładzie ustnym na przykład można dostrzec spore różnice między przekładem symultanicznym, który w swej linearności z oczywistych przyczyn zbliża się do przekładu maszynowego, a przekładem konsekutywnym, gdzie tłumacze przestawiają czasami nawet całe segmenty tekstu ${ }^{7}$ Relokacja ma też często miejsce w przekładzie literackim, szczególnie w przekładzie poezji ze względu na wymogi formalne (rym, rytm).

Umiejętność całościowej interpretacji tekstu rozważana jest przez teoretyków przekładu między innymi w kontekście kompetencji hermeneutycznych ${ }^{8}$ i tekstowych ${ }^{9}$, jednak Bukowski słusznie zadaje pytanie: „,óż to właściwie znaczy zrozumieć tekst w sposób pełny i prawdziwy" ${ }^{10}$, podkreślając, że rozumienie ,nie polega na dekodowaniu jednostek czy struktur językowych tekstu wyjściowego"11,

${ }^{4}$ Por. H. Risku, Translatorische Kompetenz. Kognitive Grundlagen des Übersetzens als Expertentätigkeit, Tübingen 1998, s. 15.

5 J. Bartmiński Tekst jako przedmiot tekstologii lingwistycznej [w:] Tekstologia, cz. 1, red. J. Bartmiński, S. Niebrzegowska-Bartmińska, Lublin 2004, s. 17.

6 W twierdzeniu tym chodzi nie tyle o sam fakt sposobu przetwarzania danych i wykorzystywania liniowych sieci neuronowych, ile o pewną linearną kolejność zdań jako podstawowych jednostek treści, które w przekładzie maszynowym nie ulegają przestawieniu. Technologia GNMT pozwala już wprawdzie osiągać obiecujące rezultaty w wymiarze całościowego traktowania tekstu, ale tego typu relokacji, którego wymaga niekiedy przekład literacki i który fachowo określa się kompensacją, nie da się w tej chwili uzyskać. W dalszej części artykułu ilustruję to na konkretnym materiale.

7 Zdarza się na przykład, że thumacze, szczególnie w sytuacji obniżonej sprawności ze względu na zmęczenie, zaczynają dany segment przekładać od końca, czyli zaczynają od elementów, które najlepiej pozostały im w pamięci, co daje im czas na lepsze kognitywne zrekonstruowanie informacji poprzedzającej.

8 Np. P. Bukowski, Hermeneutyczne kompetencje thumacza [w:] Kompetencje thumacza, red. M. Piotrowska, A. Czesak, A. Gomola, S. Tyupa, Kraków 2012.

9 O kompetencji tej mówi np. norma PN-EN 15038:2006, cyt. za: J. Dybiec-Grajer, Zmierzyć przektad? Z metodologii oceniania w dydaktyce przekładu pisemnego, Kraków 2013, s. 61.

10 P. Bukowski, op. cit., s. 128.

11 Ibid. 
W związku z czym ważna jest odpowiedź, „ku czemu zwraca się zrozumienie"12. Kompetencja rozumienia jest kompetencją tłumacza-człowieka, maszyna natomiast potrafi dekodować jednostki bez ich rozumienia i całe wysiłki podejmowane w celu optymalizacji przekładu automatycznego polegają na takim udoskonaleniu procesów przekładu maszynowego, w którym odkrycie semantycznych prawidłowości dystrybucji oraz zastosowanie metod statystycznych zastąpi w sposób możliwie doskonały rozumienie ludzkie ${ }^{13}$. Wszakże jest to możliwe wyłącznie tam, gdzie łączliwość jest konwencjonalna, a teksty służą prymarnie przekazaniu informacji. Ponadto metoda dystrybucyjna zakłada istnienie bliskich związków semantycznych w przypadku niewielkiej odległości linearnej w tekście, natomiast rozumienie ludzkie jest w stanie łączyć jednostki oddalone od siebie o wiele tysięcy znaków i wiele tysięcy lat. Stąd umiejętność ustanowienia i sensownego odczytania relacji zarówno między elementami tekstu, jak i elementami szeroko pojętego uniwersum, w którym tekst się pojawia i do którego autor tekstu - świadomie bądź nie - nawiązuje, jest kolejną kompetencją tłumacza, również często przez teoretyków przywoływaną, choć różnie nazywaną. Na przykład w modelu kompetencji tłumaczeniowej według Kelly ${ }^{14}$ występują takie kompetencje, jak kompetencja kulturowa, tematyczna, interpersonalna, odnoszące się do owego „kontekstu mowy”, którego ustalenie jest dla rozumienia i przekładu niezbędne ${ }^{15}$, gdyż domagają się tego teksty jako „byty indywidualne, nadsumatywne i wieloperspektywiczne”16.

Umiejętność ustanawiania relacji wiąże się z kompetencją intertekstualną tłumacza. Może ona się różnie manifestować, nie chodzi tutaj bowiem li tylko o odkrywanie relacji tekstu oryginału do innych tekstów, ale również o nowe korelacje, które tłumacz tworzy świadomie bądź nieświadomie. Oczywiście, mówiąc o kompetencji, mam na myśli nawiązania świadome, szczególnie w sytuacji, gdy tłumacz chce, by były one czytelne. Nieświadome korelacje to przede wszystkim ślady lekturowe tłumacza, które wpływają na przekład, takie jak zapożyczenia stylistyczne w języku przekładu, gdy ktoś na przykład tłumaczy Mrożkiem albo Sienkiewiczem. Maszyna wprawdzie na pierwszy rzut oka również kojarzy teksty, ale skojarzenia maszynowe są oczywiście w dużej mierze przypadkowe i rzadko kiedy spójne. Należy tu jednak podkreślić postęp przekładu automatycznego w przypadku korelowania tekstów fachowych odnoszących się na przykład do dyrektyw unijnych. Tutaj automat jest czasami nawet w stanie przewyższyć człowieka (szczególnie w aspekcie tempa korelowania).

12 Ibid.

13 Por. M. Eder, Znaczenie definiowane przez kontekst: uwagi o semantyce dystrybucyjnej, wystąpienie podczas konferencji „Tertium”, Kraków, 2018.

14 D. Kelly, Un modelo de competencia traductora: bases para el diseño curricular, „Puentes: hacia nuevas investigaciones en la mediación intercultural” 2002; por. też J. Albin, Kompetencja z punktu widzenia ttumacza [w:] Kompetencje thumacza, red. M. Piotrowska, A. Czesak, A. Gomola, S. Tyupa, Kraków 2012, s. 34.

15 J. Grondin, Die hermeneutische Dimension der Übersetzung [w:] Übersetzen, Verstehen, Brücken bauen, cz. 1, red. A.P. Frank, K.-J. Maaß, F. Paul, H. Turk, Berlin 1993, s. 156, tu za: P. Bukowski, op. cit., s. 134.

16 Bukowski, op. cit., s. 134. 
Umiejętność całościowej interpretacji semantycznej i komunikatywnej dotyczy przede wszystkim zdolności określania prymarnej funkcji tekstu oraz jego funkcji sekundarnych, jak również ustalania ich hierarchii. Za Jakobsonem przyjmuję, że komunikaty słowne spełniają zwykle kilka funkcji równocześnie, dlatego „[o]dmienność każdorazowego aktu mowy polega nie na monopolu którejś z tych funkcji, ale na odmiennym porządku hierarchicznym funkcji. Struktura słowna komunikatu zależy przede wszystkim od funkcji dominującej"17. Umiejętność analizy tekstu pod względem funkcji językowych i ich odpowiedniahierarchizacja jest jedna z podstawowych kompetencji tłumacza i jako taka była już niejednokrotnie opisywana w formie postulatu ustalenia hierarchii inwariantów ${ }^{18}$.

Z hierarchizacją i relokacją elementów wiąże się kolejne zaproponowane przeze mnie prawo przekładu, a mianowicie prawo kompozycji ${ }^{19}$. Odwołuje się ono do wysuniętego przez Radegundis Stolze postulatu „nierozpatrywania poszczególnych elementów w oderwaniu od całości" ${ }^{20}$. Prawo kompozycji głosi, że

odpowiedni układ elementów wykorzystanych w przekładzie daje w efekcie tekst zgodny z oryginałem (równoznaczny bądź równowartościowy, bądź równokształtny), czyli oddaje istotę oryginału, natomiast nie jest konieczne, by każdy element zbioru N1 odtwarzał odpowiedni element zbioru $\mathrm{N}^{21}$.

Prawo kompozycji nie dotyczy tylko relokacji, ale wszystkich tych zabiegów, które stosuje thumacz, aby uzyskać - zgodnie z ideą, czy inaczej: istotą oryginału - w języku docelowym tekst równoznaczny, równowartościowy bądź równokształtny ${ }^{22}$. Prawo kompozycji usprawiedliwia między innymi zabiegi, które zwykło się określać mianem kompensacji.

W zależności od rodzaju tekstu i typu przekładu swoboda kompozycyjna tłumacza będzie się różniła, dlatego mamy w tym przypadku do czynienia ze zjawiskiem skalarnym, natomiast w ograniczonym sensie element relokacji i kompozycji wystąpi nawet w przekładzie maszynowym (na przykład gdy konieczne są permutacje składniowe).

Prawo kompozycji zakłada w domyśle, że są różne możliwości kompozycji tekstu, co w połączeniu z postrzeganiem tekstu jako całości czyni pożądaną następną kompetencję, którą jest kompetencja strategiczna. By zrozumieć, na czym polega kompetencja strategiczna, trzeba odwołać się do koncepcji przekładu jako

17 R. Jakobson, Poetyka wświetle językoznawstwa, „Pamiętnik Literacki” 1960, nr 51/52, s. 435.

18 Por. np. J. Albrecht, Invarianz, Äquivalenz, Adäquatheit [w:] Übersetzungswissenschaft. Ergebnisse und Perspektiven. Festschrift für Wolfram Wilss zum 65. Geburtstag, red. R. Arntz, G. Thome, Tübingen 1990, s. 71-81.

19 J. Kubaszczyk, Czy przektadoznawstwo..., s. 24-26.

20 R. Stolze, Ttumaczenie jako proces ewolucyjny, w: Wspótczesne teorie przekładu. Antologia, red. M. Heydel, P. Bukowski, Kraków [1992] 2009, s. 353.

21 J. Kubaszczyk, Czy przekładoznawstwo..., s. 24.

22 Por. J. Ziomek, Przekład-rozumienie-interpretacja, [w:] Polska myśl przekładoznawcza. Antologia, red. M. Heydel, P. de Bończa Bukowski, Kraków [1979/1980] 2013, s. 173. Ziomek proponuje użycie terminu równoznaczności dla odpowiedniości na poziomie relacji semantycznej, równowartości w odniesieniu do relacji pragmatycznej oraz równokształtności, gdy dotyczy ona relacji syntaktycznej. 
gry ${ }^{23}$. Tłumacz posiadający kompetencję strategiczną potrafi konstruować kompletny i spójny plan działania uwzględniający wszystkie możliwe sytuacje oraz podejmować optymalne decyzje w sytuacji konfliktu. Kompetencji strategicznej nie posiada maszyna, stąd automat ,przekłada przypadkowo, bez strategii, podejmując decyzje niepowiązane, «od ruchu do ruchu», nie pamiętając o poprzednich rozstrzygnięciach i nie uwzględniając zmian z nich wypływających"24.

Kompetencja strategiczna ${ }^{25}$ wiąże się z kolejnym prawem przekładu, głoszącym, że w sytuacji przekładu tłumacz powinien dążyć rozwiązań optymalnych, czyli do „największej korzyści kosztem najmniejszych strat”26. Tłumacz o kompetencjach strategicznych w celu uzyskania przekładu optymalnego ustala ogólne cele, które chce zrealizować, oraz ewentualnie cele cząstkowe o szczególnej wadze. Prawo optymalizacji przejawia się też wysiłkach podejmowanych przez tłumaczy w celu poprawienia i udoskonalenia własnych rozwiązań. W przekładzie ustnym są to autokorekty, w przekładzie pisemnym - kolejne korekty pierwszej wersji, a nawet nowe przekłady mające ulepszyć pierwotne rozwiązania. Również prawo optymalizacji odnosi się do działalności tłumacza ludzkiego. Rozważając różnice między przekładem maszynowym a ludzkim, podkreślić należy kognitywny czynnik ,niezadowolenia”, nieusatysfakcjonowania z osiągniętego rozwiązania. Maszyna - mówiąc metaforycznie - zawsze jest „zadowolona" z efektu, z outputu. Nie potrafi bowiem ewaluować własnych rozwiązań, nie ma możliwości odpowiedzenia sobie na pytanie, czy zaspokoiła wymagania. Automat w danym momencie czasowym nie produkuje też optymalizacji. Czasami translatory pokazują możliwość rozwiązań alternatywnych, ale optymalizacji musi dokonać zawsze człowiek. Nie oznacza to, że przekłady maszynowe nie ulegają poprawie, gdyż jak wiadomo, dzięki zastosowaniu technologii głębokich sieci neuronowych systemy do thumaczenia automatycznego są coraz doskonalsze. Uczą się jako całość, na bieżąco uzupełniając informacje, i może się zdarzyć, że kolejny input tej samej frazy da lepszy output. Jednak zasadniczo, co potwierdził poczyniony na potrzeby niniejszego artykułu i opisany poniżej eksperyment, maszyna nawet po wielu dniach (ponad miesiąc) generuje to samo rozwiązanie ${ }^{27}$.

23 Koncepcję tę prezentuje np. Jiří Levý, który zauważa, że ,proces tłumaczenia ma postać g r y z pełną informa c ją - gry, w której na każdy kolejny ruch wpływa znajomość poprzednich decyzji oraz wynikła z nich sytuacja” (J. Levý, Przekład jako proces podejmowania decyzji [w:] Współczesne teorie przekładu. Antologia, red. M. Heydel, P. Bukowski, Kraków [1967] 2009, s. 73).

24 J. Kubaszczyk, O ocenianiu i ewaluacji $w$ translatoryce $w$ kontekście rozumienia przekładu jako gry, „Homo Ludens” 2017, nr 1(10), s. 133-149.

25 Kompetencję strategiczną można rozpatrywać w odniesieniu do różnych rodzajów przekładu. W odniesieniu do przekładu ustnego Daniel Gile sformułował tzw. effort models, ażeby pomóc tłumaczom rozwijać odpowiednie strategie i taktykę; por. D. Gile, Basic Theoretical Components in Interpreter and Translator Training [w:] Teaching Translation and Interpreting: Training, Talent and Experience, red. C. Dollerup, A. Loddegaard, Amsterdam 1992, s. 191. Por. też tzw. zasada minimax w teorii gier, do której m.in. odwołuje się też Levý (op. cit.).

26 J. Kubaszczyk, Czy przekładoznawstwo..., s. 23-24.

27 Eksperymentalnie, trzykrotnie w dniach 28.02.2018, 1.3.2018 i 3.04.2018, został automatycznie przełożony fragment wiersza Ryby J. Brzechwy, brzmiący: „Karaś milczał. Tylko kilka // Jeszcze słów rzuciła kilka", co opisuję bardziej szczegółowo w dalszej części artykułu. 
Człowiek natomiast bywa ze swego przekładu niezadowolony. Jeżeli jego dzieło go nie satysfakcjonuje, próbuje je poprawić, ulepszyć, powtórzyć, tak aby w rezultacie otrzymać produkt jeżeli nie idealny, to przynajmniej optymalny. W związku z tym powstaje wiele alternatywnych rozwiązań. Możliwość optymalizacji wynika z kolejnych praw przekładu, stwierdzających, że „dowolny znak x (zdanie X, tekst X) można przetłumaczyć (w sposób poprawny) różnie"28, w związku z czym ,[n] [ie da się w sposób pewny przewidzieć, jak będzie brzmiało tłumaczenie"29. By uniknąć zarzutu, że takie spojrzenie na przekład jest wyrazem swoistego relatywizmu, liberalizmu i permisywizmu, postawy ,wszystko-mi-wolno", trzeba przywołać dwa kolejne prawa, a mianowicie prawo głoszące, $i \dot{z}$, pierwszorzędnym celem przekładu jest reprezentacja oryginału” ${ }^{30}$ oraz że „[p]rzekład powinien być zgodny z oryginałem"31.

Kolejna kompetencja tłumacza polega na umiejętności uzgodnienia, czyli ustalenia, na czym owa zgodność ma polegać (co wiąże się między innymi z omawianym na wstępie prawem idei). Jednocześnie dobry przekład można zwykle uzyskać dopiero przez zdystansowanie się w pewien sposób od oryginału, oderwanie się od niego, o czym dobrze wiedzą tłumacze korygujący swe teksty i usuwający niepożądane kalki w oderwaniu od oryginału, w pewnym dystansie czasowym od samego procesu przekładu. U podstaw leży tutaj kolejne prawo, głoszące, iż: „«To samo» w przekładzie powstaje przez zaniechanie identyczności”32. Także w tym przypadku mamy do czynienia ze zjawiskiem skalarnym. Owo zaniechanie identyczności będzie wyglądało inaczej w przekładzie specjalistycznym, inaczej w przekładzie poezji. Zawsze jest jednak ,,przynajmniej jedna rzecz/aspekt/wymiar, w którym przekład różni się od oryginału"33, bo ,[z]akłócenie podobieństwa jest immanentną cechą przekładu" ${ }^{34}$. Bierze się to między innymi stąd, że na przekład „ma wpływ szereg czynników wewnątrztekstowych i zewnętrznych" 35 . $\mathrm{Z}$ faktu, że od kompetencji hermeneutycznych tłumacza zależy odczytanie, że to thumacz obiera strategię, że to on dokonuje kompozycji i optymalizacji, wynika też osobisty ślad tłumacza, który odciska się na przekładzie: „W przekładzie obok głosu autora zawsze jest pewien pierwiastek pochodzący od tłumacza, wynikający z jego odczytania, przekład jest dialogiem albo polilogiem"36. Takiego osobistego, twórczego śladu trudno oczywiście doszukiwać się w przekładzie maszynowym, który jest wynikiem szeregu operacji matematycznych. Ów osobisty ślad może być - szczególnie w przypadku tekstów literackich - wartością dodaną, może tworzyć nową kulturę, nowy język. I na koniec, skoro niezadowolony tłumacz może w nieskończoność poprawiać swe dzieło, można stwierdzić, że tekstu z natury rzeczy nie da się nigdy przetłumaczyć definitywnie, zawsze bowiem jest

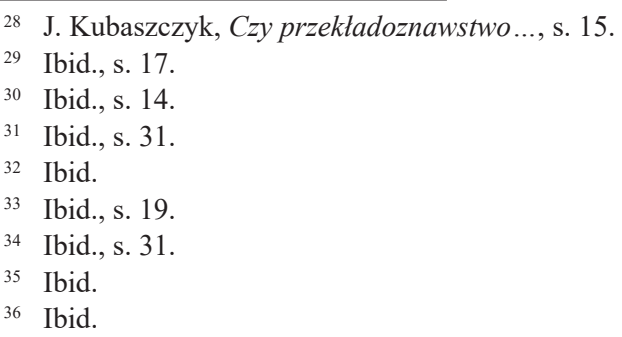


jakiś potencjał zmiany, poprawy, wynikający z innych odczytań, uwarunkowań, kompetencji i predyspozycji thumacza. Tak zwana wersja ostateczna jest zatem kwestią umowną i koncesją wobec rzeczywistości ekonomicznej (mam tu na myśli również ekonomię czasu oraz innych zasobów). Kompetencja thumacza to zatem również wiedza, kiedy skończyć grę w konkretny przekład, kiedy uznać go za ukończony.

I w końcu prawo przekładu, które w porządku logicznym jest prawem pierwszym. Mówi ono, że „,[n]ie istnieje przekład bez oryginału, oryginał jest zewnętrzną racją bytu przekładu" ${ }^{37}$. Na pewno jest to bardziej ewidentne w przekładzie maszynowym, gdzie output zawsze występuje bezpośrednio po inpucie, a relacje przyczynowo-skutkowe są oczywiste. Jak wiadomo, w przypadku przekładów ludzkich z tą ewidencją bywa różnie i czasami ustalenie rodzaju relacji jest trudne. Udowodnienie, że dany tekst jest przekładem, czyli takim przetworzeniem oryginału, który spełnia zdefiniowane uprzednio przez badacza kryterium zgodności, może wymagać dość żmudnych badań. Podobnie konieczne jest odpowiednie instrumentarium ewaluacyjne, by tekst mieniący się przekładem sfalsyfikować jako nieprzekład (i uznać na przykład za dzieło inspirowane lub w pełni oryginalne). W obliczu tego prawa kompetencja thumacza polega na pokorze wobec tekstu pierwszego, jeżeli ma on być czymś więcej niż tylko niewiążącą inspiracją dla własnej twórczości.

$$
\text { *** }
$$

Jak prawa przekładu funkcjonują w praktyce? Jakie inne kompetencje, oprócz już wymienionych, powinien posiadać tłumacz ludzki, który zamierza przełożyć tekst literacki? Na te pytania postaram się odpowiedzieć, opierając się na fragmencie wiersza Jana Brzechwy Ryby ${ }^{38}$. Rozpocząć trzeba od przeprowadzenia analizy i interpretacji wiersza, umożliwiającej postawienie hipotezy dzieła jako całości ${ }^{39}$, oraz od ustalenia kontekstu mowy ${ }^{40}$.

37 Ibid.

38 J. Brzechwa, Ryby [w:] Wiersze dla dzieci, wyb. K. Tes, Poznań 2017.

39 Zgodnie z postulatem Janusza Sławińskiego, który pisał: „Jest rzeczą pożądaną, aby właściwie odróżniać poziom interpretacji dzieła od poziomu jego opisu, czy też inaczej mówiąc: analizy. Jeśli opis obejmuje to, co w utworze zaktualizowane, znajdujące się na powierzchni i standardowe, to interpretacja jest próbą dotarcia do jakiejś potencjalnej sfery utworu, na którą składają się reguły określające jego, i tylko jego, całościowy charakter. Każda interpretacja zdaje się zakładać dwoistą modalność wypowiedzi literackiej - jawną i utajoną, eksplikowaną i implikowaną. Oczywiście, w różnych rodzajach strategii interpretacyjnych rozmaicie wygląda sposób przechodzenia od jednej do drugiej, zawsze jednak będzie to przechodzenie od pewnych właściwości danych do warunków potencjalnych, od objawów do motywów, od zbioru cech do systemu znaczeń, od tekstu dostępnego w postaci linearnego przebiegu do jakiejś »gramatyki«, która ten przebieg projektuje. [...] Interpretacja mówiąc najkrócej - to hipoteza ukrytej całości utworu”. Por. J. Sławiński, O problemach „,sztuki interpretacji”, http://hamlet.edu.pl/slawinskij-szt-int (dostęp: 5.10.2019).

40 Wspomniany już Sławiński odnośnie do kontekstu zauważa: ,interpretacja jest zawsze w mniejszym lub większym stopniu usiłowaniem zmierzającym do identyfikacji kontekstu trafnie tłumaczącego utwór. Badacz formułuje nie tylko hipotezę całości dzieła, ale także propozycję kontekstu, który całość tę oświetla. [...] Czym jednak jest - ów kontekst? Wydaje się, że należy go rozumieć dwojako. 
Tekst ukazał się w tomiku Wiersze dla dzieci, można zatem wstępnie założyć, że Ryby to tekst literacki adresowany do dziecka. Autorem jest Jan Brzechwa (właściwie Jan Wiktor Lesman), polski poeta I połowy XX wieku (ur. 1898, zm. 1966), mający - jak sam o sobie mówił - „od dziecka zgubną skłonność do rymowania"41. Brzechwa obok swej działalności satyrycznej pisał liczne utwory dla dzieci, które wyśmienicie łączyły trzy tradycyjnie przypisywane literaturze funkcje, to znaczy uczyły, bawiły i wychowywały.

Wiersz Ryby dostarcza młodemu czytelnikowi wprawdzie pewnych informacji, między innymi zapoznaje go z nazwami różnych gatunków ryb, ale jego prymarną funkcją nie jest funkcja poznawcza, lecz poetycka, gdyż opowieść o rybich przekomarzaniach to zabawna „sztuka dla sztuki”, a zatem „skupienie się na komunikacie dla niego samego" " Jeżeli najważniejszy nie jest przekaz informacji, czyli funkcja poznawcza, to w przekładzie - przy spełnieniu określonych warunków - dopuszczalne jest celowe pominięcie pewnych informacji albo zastąpienie ich innymi informacjami. Twierdzę, że przy obecnym rozwoju techniki takiej operacji nie dokona maszyna, co ogranicza przekład maszynowy do tekstów $\mathrm{z}$ dominującą funkcją poznawczą ${ }^{43}$. Łatwo to udowodnić, zadając translatorowi automatycznemu przekład wiersza z dominującą funkcją poetycką, jak utwór Urodziny Wisławy Szymborskiej, o którym wspominam we wstępie, albo jak omawiany tutaj wiersz Ryby. Przekład maszynowy drugiej strofy tegoż utworu odtwarza mniej więcej zawarte w tym fragmencie informacje (choć nie całkiem dokładnie, w polszczyźnie mamy liczbę mnogą „łososie”), jednak całkowicie pominięta zostaje funkcja poetycka:

„Karpie dobre są, lecz w sosie” -

Odezwały się łososie.
„Karpfen sind gut, aber in Soße”-

Lachs meldete sich.

Dzięki opisanym powyżej kompetencjom tłumacz ludzki, poszukujący pośród różnych możliwych wariantów wersji optymalnej, uzyskuje natomiast zdecydowanie lepszy efekt, starając się przynajmniej częściowo odtworzyć funkcję poetycką (przekład własny):

In der Sauce - so Salme gemein -

Z jednej strony konkretne dzieło tkwi wśród tych okoliczności historycznoliterackich i socjopsychologicznych, które towarzyszyły jego powstawaniu i które dostępne są w drodze rekonstrukcji. Jest to macierzysty kontekst utworu. $Z$ drugiej strony dzieło takie zostaje odniesione do kultury literackiej interpretatora, do jego wrażliwości, gustów i zapatrywań ukształtowanych przez bliskie mu tradycje i poetyki, a także do tych norm i postulatów, które głosi, gdy usiłuje wpływać na bieg zdarzeń literackich w swojej współczesności. Oczywiście, oba te rodzaje kontekstów są równoczesne, ale nie są równorzędne. W zależności od tego, który z nich uzyskuje większą wyrazistość, kształtują się dwa typy podejścia interpretacyjnego, w krańcowych wypadkach zdecydowanie opozycyjne: interpretacja historycznoliteracka i interpretacja krytycznoliteracka”. Por. ibid.

${ }_{41}$ J. Brzechwa, Na marginesie [w:] Dymek z papierosa czyli wspomnienia o scenach, scenkach i nadscenkach, red. K. Rudzki, Warszawa 1959.

42 R. Jakobson, op. cit., s. 439.

43 Nie oznacza to, że jest to w ogóle niemożliwe i że nie da się stworzyć algorytmów umożliwiających przekład albo raczej wspomaganie przekładu poezji. Dosyć łatwo można sobie wyobrazić oprogramowanie wspomagające wyszukiwanie odpowiednich rymów. 
Schmecken Karpfen besonders fein

„In der Tunke“ - so die Salme -

„schmecken Karpfen äußerst feine“.

Zdarza się wprawdzie, że maszyna zastępuje informacje, ale na zasadzie błędnego przyporządkowania, a nie zamierzonego dostosowania. Łatwo to udowodnić na przykładzie omawianego wiersza. W zwrotce trzeciej trzy razy występuje „flądra":

„Głupie żarty” - rzekła flądra.

„Patrzcie, flądra jaka mądra,

Skąd u flądry rozum taki?" -

Obruszyły się szczupaki.

W maszynowym przekładzie w pierwszym wystąpieniu rzeczownik ten zostaje przetłumaczony jako „Scholle” (gładzica), a w dwóch następnych jako „Flunder", jest to jednak rozwiązanie przypadkowe, niesłużące żadnemu celowi. Co więcej, gdyby faktycznie pojawiło się w przekładzie, mogłoby zdezorientować dziecięcego czytelnika:

*,Dumme Witze”, sagte die Scholle.

„Schau, Flunder so weise,

Woher kommt dieser Grund in der Flunder? "-

Pike stieg aus dem Haken.

Pomijając kwestię ewidentnych błędów i niegramatyczności, obserwujemy tutaj tłumaczenie słowo po słowie, a nie rozwiązanie całościowe, co potwierdza słuszność wywodów z pierwszej części artykułu. I znowu przekład ludzki okazuje się z omówionych wcześniej powodów doskonalszy (przekład własny):

Blöde Witze - sagt die Flunder.

„Solch ein Köpfchen ist ein Wunder,

Ist der Flunder Vernunft echt?"“

Überlegte mancher Hecht.

Wiersz Ryby napisany został regularnym ośmiozgłoskowcem trocheicznym (ó oznacza sylabę akcentowaną, dywiz nieakcentowaną):

ó - ó - ó - ó-

ó - ó-ó-ó -

W jednej ze zwrotek występuje bardzo ciekawe zjawisko epanadiplozy. Epanadiploza to figura stylistyczna polegająca na powtórzeniu tego samego wyrazu na początku i końcu zdania lub innego segmentu wypowiedzi ${ }^{44}$. Tworząc epanadiplozę, Brzechwa wykorzystał homofonię nazwy ryby z rodziny śledziowatych, nazywanej inaczej tiulką (łac. Clupeonella cultriventris), oraz zaimka oznaczającego „W sposób przybliżony liczbę większą niż 2 i mniejszą niż 10 ”45. Ponadto odpowiednie usytuowanie pozostałych wyrazów w zdaniu pozwoliło

44 Por. https://sjp.pl/epanadiploza (dostęp: 28.11.2019).

45 Zob. https://sjp.pwn.pl/sjp/kilka_I (dostęp: 1.03.2018). 
uzyskać poecie efekt parafonii. Dwa sąsiadujące wersy zamykają wyrazy homofoniczne, poeta zastosował zatem rym homonimiczny, zwany także homorymem:

\section{Karaś milczał. Tylko kilka}

Jeszcze słów rzuciła kilka.

Gdybyśmy założyli, że każdy element zbioru $\mathrm{N}_{1}$ musi odtworzyć odpowiedni element zbioru $\mathrm{N}$, to możliwe, że otrzymalibyśmy tekst równoznaczny, ale na pewno nie równowartościowy i równokształtny. Pozostalibyśmy wtedy na poziomie automatycznego translatora. Maszyna ma zakodowane, że każdy element zbioru $\mathrm{N}_{1}$ musi odtworzyć odpowiedni element zbioru $\mathrm{N}$, choć w zaawansowanym technologicznie przekładzie maszynowym można dostrzec, że programy do przekładu automatycznego potrafią już stosować w ograniczonym zakresie relokację elementów oraz czasami oddawać jeden znak za pomocą kilku lub kilka za pomocą jednego, co pokazuje egzemplarycznie próba przepuszczenia omawianej zwrotki wiersza przez Tłumacza Google. W rezultacie otrzymujemy taki oto wynik, oczywiście niespecjalnie zadowalający:

*Karaś war still. Nur ein paar

Sie sagte ein paar Worte ${ }^{46}$.

Podobnie niezadowalający rezultat otrzymujemy, zadawszy translatorowi przekład angielski:

*Karas was silent. Only a few

She said a few more words ${ }^{47}$.

By odpowiednio poradzić sobie z przekładem tego fragmentu, potrzebna jest specjalna kompetencja, nazywana kompetencją literacką, której maszyna do przekładu nie posiada.

Czym jest jednak kompetencja literacka? Pozwala ona stwierdzić, że identyczne brzmienie występujących w pobliżu wyrazów może być istotne i realizować funkcję, którą zwykło się za Jakobsonem określać funkcją poetycką języka. Jakobson, określając empiryczne kryterium językoznawcze dla funkcji poetyckiej, odwołuje się do wyboru i kombinacji jako dwóch podstawowych operacji językowych $^{48}$.

Tematem wiersza Ryby są rybie przekomarzanki. Analizując utwór, zauważyć możemy, że poeta z obszernego zbioru kohiponimów tytułowego hiperonimu wybrał niektóre, reprezentujące ryby rzeczne bądź morskie, jednak wyborem konkretnych gatunków rządzi przede wszystkim zasada kombinacji, można powiedzieć, odwołując się do znanego wiersza Christiana Morgensterna, że Brzechwa uczynił to „um des Reimes willen”49, czyli z uwagi na rym. Mamy zatem następujące pary rymów: szarpie - karpie, sosie - tososie, flądra - mądra, taki

46 Przekład Google, 28.02.2018.

47 Przekład Google, 5.10.2019.

48 R. Jakobson, op. cit., s. 440.

49 Ch. Morgenstern, Das ästhetische Wiesel, http://signaturen-magazin.de/christian-morgenstern--das-aesthetische-wiesel.html (dostęp: 21.11.2018). 
- szczupaki, sandacza - uwłacza, słodka - płotka, kilka - kilka. Pod względem typologicznym najciekawsze są wśród nich rymy echowe, inaczej półhomorymy sosie - tososie (także bez nazw ryb, jak rzeczne - niedorzeczne), oraz będący przedmiotem naszej szczególnej uwagi homorym kilka - kilka. Wedle Jakobsona:

Wybór dokonuje się na bazie EKWIWALENCJI, podobieństwa lub różnicy, synonimiki czy antonimiki, podczas gdy kombinacja - potrzebna do zbudowania szeregu - powstaje na bazie PRZYLEGŁOŚCI. Funkcja poetycka - to projekcja zasady ekwiwalencji z osi wyboru na oś kombinacji: ekwiwalencja staje się konstytutywnym chwytem szeregu ${ }^{50}$.

Ponieważ w tekście dominuje funkcja poetycka, jego przekład wymaga kompetencji poetyckiej, czyli umiejętności projekcji ,zasady ekwiwalencji z osi wyboru na oś kombinacji”"

W przekładzie omawianego utworu priorytetem jest oddanie regularności wiersza, jego metrum, powinny pojawić się w nim homorymy, półhomorymy oraz w optymalnym przypadku również epanadiploza, homofonia i parafonia jako chwyty par excellence literackie (ich wystąpienia w potocznym użyciu języka są wartościowane $\mathrm{z}$ reguły negatywnie). Czy jednak muszą się one pojawić w tym samym miejscu? Jak się wydaje, nie, jak bowiem podkreśla Jakobson: „poetyckość bynajmniej nie jest doczepieniem ornamentu retorycznego do wypowiedzi, ale pełnym przewartościowaniem wypowiedzi i wszystkich jej komponentów"s2. Twierdzenie to odnosi się również, w duchu wcześniejszych wywodów, do przekładu.

Przekład to według Stolze „nieskończone w swej istocie ewolucyjne poszukiwanie"53. Cóż zatem robi thumacz? Stosując różne kombinacje, próbuje skomponować tekst tak, ażeby w przekładzie uzyskać jak najwięcej znaczników literackości, nie oddalając się zbytnio od istoty opowieści, czyli zachowując, jeżeli to możliwe, funkcję poznawczą, która w tym utworze jest jednak zdecydowanie drugorzędna. Na osi wyboru szuka elementów spełniających istotne dla tego utworu kryterium podobieństwa (na przykład rytmicznego, wygłosowego, równokształtności), posiłkując się przy tym synonimią i antonimią, by potem uzyskane wyniki rzutować na oś kombinacji.

Pragnąc wykreować w przekładzie homorym, może go relokować, dzięki czemu zachowa walory poetyckie wiersza jako całości, na przykład przekładając czwartą zwrotkę następująco (niestety kosztem regularnego metrum) ${ }^{54}$ :

Mruknął sandacz. Więc sandacza

Zbeształ okoń: „Pan uwłacza

Mnie i całej mej rodzinie,

Niech Pan od nas precz odpłynie!”
Brummt der Zander. Worauf der Barsch

Äußerte sich erstaunlich barsch:

„Sie täten uns den Gefallen,

Schwämmen Sie weg von uns allen!“

$50 \quad$ R. Jakobson, op. cit., s. 441.

51 Ibid.

52 Ibid., s. 472.

53 R. Stolze, op. cit., s. 354.

54 Przekład własny. 
Jedno z przywołanych wcześniej praw przekładu zawiera twierdzenie, że „to samo" w przekładzie powstaje przez zaniechanie identyczności. Jest to szczególnie widoczne właśnie w przekładzie, w którym dominuje funkcja poetycka. Umberto Eco mówi o „quasi” przekładu poetyckiego, podkreślając, że w przekładzie w ogóle „w najlepszym przypadku mówi się quasi to samo innymi słowy” ${ }^{55}$, natomiast

przy przekładzie tekstów poetyckich problem owego quasi staje się punktem centralnym i zajmuje cały obszar - aż po granicę udanej poetyckiej rekreacji (Nachdichtung), która jest tak genialna, że przechodzi się od quasi tego samego do czegoś innego, do czegoś nowego, będącego dłużnikiem oryginału tylko niejako moralnie ${ }^{56}$.

Interesującą kwestią jest przy tym, jak podsumowuje Eco, móc obserwować, „kiedy i gdzie tłumacze czasami zaczynają poszukiwać istoty rzeczy, którą pragną oddać za wszelką cenę (nawet jeśli tylko quasi) - dobrze wiedząc, że mogą powiedzieć tylko quasi to samo"57. Owo poszukiwanie istoty rzeczy sprowadza nas na powrót do początków niniejszych rozważań, gdyż owa istota rzeczy to nic innego jak idea oryginału, stanowiąca wzór dla przekładu i jego rację bytu.

\section{Bibliografia}

Albin J., Kompetencja z punktu widzenia ttumacza [w:] Kompetencje ttumacza, red. M. Piotrowska, A. Czesak, A. Gomola, S. Tyupa, Kraków 2012, s. 31-48.

Albrecht J., Invarianz, Äquivalenz, Adäquatheit [w:] Übersetzungswissenschaft. Ergebnisse und Perspektiven. Festschrift für Wolfram Wilss zum 65. Geburtstag, red. R. Arntz, G. Thome, Tübingen1990, s. 71-81.

Barańczak S., Ocalone $w$ ttumaczeniu. Szkice o warsztacie tłumacza poezji z dodatkiem małej antologii przekładów-problemów, wyd. 3, Kraków 2004.

Bartmiński J., Tekst jako przedmiot tekstologii lingwistycznej [w:] Tekstologia, cz. 1, red. J. Bartmiński, S. Niebrzegowska-Bartmińska, Lublin 2004, s. 9-24.

Brzechwa J., Na marginesie [w:] Dymek z papierosa czyli wspomnienia o scenach, scenkach i nadscenkach, red. K. Rudzki, Warszawa 1959.

Brzechwa J., Ryby [w:] Wiersze dla dzieci, wyb. K. Tes, Poznań 2017.

Bukowski P., Hermeneutyczne kompetencje tłumacza [w:] Kompetencje tłumacza, red. M. Piotrowska, A. Czesak, A. Gomola, S. Tyupa, Kraków 2012.

Dybiec-Gajer J., Zmierzyć przekład? Z metodologii oceniania $w$ dydaktyce przekładu pisemnego, Kraków 2013.

Eco U., Quasi dasselbe mit anderen Worten. Über das Übersetzen, München [2009] 2014.

55 U. Eco, Quasi dasselbe mit anderen Worten. Über das Übersetzen, München [2009] 2014, s. 328 (tłumaczenie z przekładu niem. - J.K.).

56 Ibid. (tłumaczenie z przekładu niem. - J.K.).

57 Ibid. (tłumaczenie z przekładu niem. - J.K.). 
Eder M., Znaczenie definiowane przez kontekst: uwagi o semantyce dystrybucyjnej, wystąpienie podczas konferencji „Tertium”, Kraków 2018.

Gile D., Basic Theoretical Components in Interpreter and Translator Training [w:] Teaching Translation and Interpreting: Training, Talent and Experience, red. C. Dollerup, A. Loddegaard, Amsterdam 1992, s. 185-194.

Grondin J., Die hermeneutische Dimension der Übersetzung [w:] Übersetzen, Verstehen, Brücken bauen, cz. 1, red. A.P. Frank, K.-J. Maaß, F. Paul, H. Turk, Berlin 1993, s. 151-157.

Jakobson R., Poetyka w świetle językoznawstwa, „Pamiętnik Literacki” 1960, nr 51/52, s. 431-473.

Kelly D., Un modelo de competencia traductora: bases para el diseño curricular, „Puentes: hacia nuevas investigaciones en la mediación intercultural” 2002.

Kubaszczyk J., O ocenianiu i ewaluacji $w$ translatoryce $w$ kontekście rozumienia przekładu jako gry, „Homo Ludens” 2017, nr 1(10), s. 133-149.

Kubaszczyk J., Czy przekładoznawstwo to nauka oparta na solidnym fundamencie? Hipoteza podstawowych praw przekładoznawstwa, ,Między Oryginałem a Przekładem" 2019, nr 2(44), s. 9-36.

Levý J., Przekład jako proces podejmowania decyzji [w:] Współczesne teorie przekładu. Antologia, red. M. Heydel, P. Bukowski, Kraków [1967] 2009, s. 72-85.

Morgenstern Ch., Das ästhetische Wiesel, http://signaturen-magazin.de/christian-morgenstern--das-aesthetische-wiesel.html (dostęp: 21.11.2018).

Risku H., Translatorische Kompetenz. Kognitive Grundlagen des Übersetzens als Expertentätigkeit, Tübingen 1998.

Sławiński J., O problemach ,,sztuki interpretacji”, http://hamlet.edu.pl/slawinskij-szt-int (dostęp: 5.10.2019).

Stolze R., Tłumaczenie jako proces ewolucyjny [w:] Współczesne teorie przekładu. Antologia, red. M. Heydel, P. Bukowski, Kraków [1992] 2009, s. 347-355.

Święch J., Przekłady i autokomentarze [w:] Polska myśl przekładoznawcza. Antologia, red. M. Heydel, P. de Bończa Bukowski, Kraków [1984] 2013, s. 193-216.

Ziomek J., Przekład - rozumienie - interpretacja [w:] Polska myśl przekładoznawcza. Antologia, red. M. Heydel, P. de Bończa Bukowski, Kraków [1979/1980] 2013, s. $163-192$. 